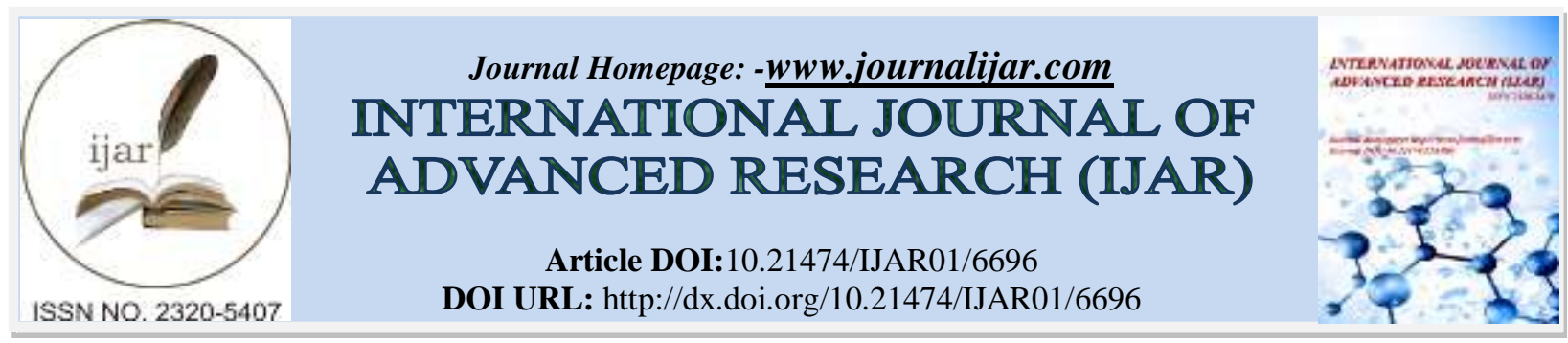

RESEARCH ARTICLE

\title{
THE CHALLENGES OF \\ SERVICE DELIVERY AND CUSTOMER SATISFACTION IN THE PUBLIC SECTOR (THE CASE OF ADAMA TRANSPORT AUTHORITY).
}

\author{
Thomas Haile (MPA). \\ Samara University, Lecturer, College of Business and Economics, Department of Management, Ethiopia.
}

\section{Manuscript Info}

\section{Manuscript History}

Received: 08 January 2018

Final Accepted: 10 February 2018

Published: March 2018

Keywords:-

New Public Management, Service

Delivery, and Customer satisfaction

\begin{abstract}
Customer satisfaction is considered a prerequisite for customer retentio $\mathrm{n}$ and loyalty, and can help to boost profitability, market share and retu rn on investment.Thus, to be successful in the current competitive envir onment, service organizations must streamline their service delivery sy stems and respond to everdiscerning customers' demands for efficie nt and quality services. Adama transport Authority is one of the publi c institutions which facilitates, coordinates and promotes private inve stment in the city administration. This term paper assessed service deli very and customer satisfaction in the transport authority in relation to lo cation, facilities, requirements and forms, transparency and participatio $\mathrm{n}$, employees' effect on service delivery and satisfaction on their job (salary, benefit and trainings), timeliness, customer satisfaction and co mplaint handling, which are the best measure of customer Satisfaction. The result of the term paper indicated that manpower and offices wit $\mathrm{h}$ the necessary, inaccessiblity of photo copy service, the existence of $p$ roblems related to location, reception area, meeting standard time,lo w salary scale, low provision of skilled based training, low incentives a nd compliant handling system are the major problems that dissatifies customer satisfaction.
\end{abstract}

Copy Right, IJAR, 2018,. All rights reserved.

\section{Introduction:-}

Lane, (2000) states that New Public Management (NPM) became the most popular during the 1980 and 1990s in r eforming the public sector. It is a theory of the most recent paradigm change in how the public sector is to be gove rned, and is part of the managerial revolution that has gone through out the world affecting all countries. Avashian d Maheshwari, (2007:86) also indicated that NPM is amongest the latest concepts to enter the lexicon of public a dministration in a bid to transform it completely. It is a merger of public and business administrations by taking the "what and "why" from public administration and "how" from business administration. The needs and nature of service of a particular reform program determines the choice of strategies to be used.

Schacter (2000:5) has identified the success factors for public sector reforms in developing countries. The loca 1 leadership and ownership of reforms, popular pressure for reform, a strong bond of accountability between citizens and the public sector, wide dissemination of information, creating organizational culture that is outcome oriented an $\mathrm{d}$ mission driven, capacity building on policymaking and implementation, and integrating downsizing programs into a large frame of reference are the factors identified. 
As Gaster and Squires, (2003:8) state public service delivery is the most important element of NPM driven publi $\mathrm{c}$ sector reforms. Public service is a term often used to mean services provided by the government to the citizens, ei ther directly (through the public sector) or indirectly by financing the private provision of the service.

Measuring service quality and customer satisfaction is a central issue to evaluate public sectors reformimplementati on even though there is a challenge that arises from the absence of universal definition of quality services and measurement indicators. But there is a general agreement among scholars in the area that quality of service sho uld be measured or judged by the customers. However, they differ on the techniques or methods of how custom er satisfaction is measured. As Leisen and Vance, (2001:308) indicated there are two schools of thought namely th e European school of though, Which includes both process and out come; and the US school of thought which focus es on process aspects of services.

Customer service is task that involves interaction with customer in person or mail. It is designed, performed and co mmunicated with two goals in mind; operational efficiency and customer satisfaction. Essentially, it embraces all personnel whose jobs bring them in to contact with customer on routine aswell as on exception basis. Such person nel become part of the over all service product even though their jobs may have been defined in strictly operatio nal term. Hence, the need to balance operational efficiency against customer satisfaction should be considered.

Donald Water (2002:9) defines quality as the ability of a product or service to meet and preferablyexceeds cust omer expectation. Kotler (2003:57) also defines quality as "the totality of features and characteristics of a produc $\mathrm{t}$ or service, which bear up on its ability to satisfy stated and implied needs .The quality of services can be particul arly difficult to measure as it relies more on the subjective opinions of customers. But among other things, it isdominated by judgments about availability, responsiveness to customers needs, competence of staff, courtesy a nd help fullness of staff, communication between participants, timeliness, and, fairness.

The Ethiopian service delivery policy (2001:1) service delivery refers to the systematic arrangement of activities i $\mathrm{n}$ service giving institutions with the aim of fulfilling needs and expectations of service users and other stakehold ers with the optimum use of resources. In short, improvement of service delivery means increasing the cost eff ectiveness, coverage and impact of services. Although the Ethiopian civil service has had a long tradition and ex perience of serving various governments, it has been until recently given little attention to improving public servic e delivery. Unfortunately, the idea that the civil service exists to serve the public good has been neglected in Ethiopi an public institutions. Therefore, in order to overcome the problem and to overhaul and enhance the civil service systemthe government embarked on a comprehensive civil service reform program of which service delive ry is a component.

Besides the federal Government of Ethiopia has issued service delivery policy in the civil service in 2001, by con sidering the fact that one of the prerequisites for service delivery improvement in the civil service is the exist ence of clearly defined policy that reflects government intentions and expectations regarding service delivery and quality of services as well as the rights and obligations of service providers and recipients in the process of ser vice delivery.

The Ethiopian civil service was fraught with problems that impeded the realization of expected outcomes. So me of the problems that limited the effectiveness of the civil service in carrying outgovernment policies and programs and consequently its role in promoting economic and social developments are: positive attitude tow ards public service has not developed to the desired extent, insufficient recognition that citizens have rights $t$ o receive services from government, lack of accountability in civil service institutions for failure to meet expecte $\mathrm{d}$ performances, etc. In addition the fact that civil service in many cases has not been able to properly address the ri ghts of service users to get public service in equitable manner have contributed to the prevailing negative perceptio $\mathrm{n}$ among the public about the efficacy of government institutions and civil servants.

Regarding services provided, Adama Zonal district level had Provided transport,communications, agriculture, educat ion, health and water services delivery to his customers. From the services delivered by adama town this term was $\mathrm{f}$ ocused on service delivered by transport authority. Adama transport authority has 51 employeswho are working in th e organization. The problem of service delivery and customer satisfaction was assessed by different scholars in differ ent organizations but this study tried to assess service delivery and customer satisfaction in the Adama transport Au thority. 


\section{Objectives of the research:-}

The objectives of this study was to assess service delivery and customer satisfaction in the Adama transport Autho rity in relation to location, facilities, requirements and forms, transparency and participation, employees' effect on se rvice delivery and satisfaction on their job (salary, benefit and trainings), timeliness,customer satisfaction and compla int handling, which are the best measure of customer satisfaction.

\section{Methodology:-}

The researcher described service delivery and customer satisfaction in the Adama transport Authority. As Abiy, et al (2009) mentioned that, such type of research called descriptive case study which describes phenomenon or event. They mentioned that case studies emphasize on specific area or locality. Public service delivery also involves all these actors. In view of this, the study was guided by descriptive case study approach. In this study, both primary and secondary data sources were used. To conduct this research, researchers used both primary and secondary data collection methods. The primary data sources collected through key informant interviews and passive observations. Secondary data sources also collected through reading of federal and ONRS constitution, government reports, policy, books, and websites.

\section{Results and Discussions of the Term Paper:-}

The result tried to assess service delivery and customer satisfaction in the Adama transport Authority in relation to location, facilities, requirements and forms, information acess, manpower avaliability, transparency an d participation, employees' effect on service delivery and satisfaction on their job (salary, benefit and traini ngs), timeliness, customer satisfaction and complaint handling,which are the best measure of customer satisfaction.

\section{Location of the areas:-}

As one of the principles of quality service states, public services as well as information about them should be acc essible to every citizen to empower them. The convenience of the location of the service area affects the quality of $s$ ervice. Thus it is necessary to evaluate the location of the authority. Accordingly. the location of the authorit $\mathrm{y}$ is inconvenient for the majority of customers. The reason why the location of the authority is inconvenient $\mathrm{w}$ ere lack of parking area, the building has no sufficient light on stairs, lack of fresh air circulation and absence st ationeries service.

\section{Reception area:-}

The authority reception area was very bad. The following factors contributed the authority's reception area to make very bad. These were the area of the reception is very small to serve manycustomers at a $t$ ime, the number of chairs is insufficient and not comfortable, lack reading materials, lack of entertainment facilities and Lack of clean and easily accessible toilet.

\section{Information Access:-}

Information is resource. So, providing complete and accurate information is an important point tohelp and empo wer customers. The authority 's service delivery with respect to getting complete an accurate information cust omers and employees were not satisfied with information access. Thus,the authority has to strive for further improvement of its information access.

\section{Employees view on fulfillment of manpower and comfortable office:-}

Having adequate manpower and well equipped office with the necessary facilities is vital for the satisfaction of employees as well as customers. But,the problems with regard to fulfilling manpower and office with the necessary $\mathrm{f}$ acilities which necessitates further effort by the authority.

\section{Employees' view on the provision of skill based trainings and incentives:-}

In order to achieve effective, efficient and economic utilization of scarce organizational resources, managers shoul $\mathrm{d}$ upgrade the skill of their staffs by providing skill based training; motivate them by giving monetary and non mon etary benefits/incentives as well as by creating favorable working conditions. In this regard, authority 's provision o f skilled based trainings and incentives is low.Thus, the authority should take into consideration the widely a ccepted view that satisfied employees will deliver quality service or improved performance and try to provide skill based trainings and incentives for its staff. 


\section{Requirements and Forms:-}

The authority 's requirements was vague. This gives a message that the authority has to evaluate its requiremen ts.So, in order to provide fast service and for the best satisfaction of its customers the authority has tomake forms as fair, few and clear.

\section{Consultation to and with customers:-}

To ensure "comprehensiveness"and "representativeness" of the service delivery, consulting service users is import ant. The authority 's consultation to and with clients during the process of its service delivery improvement was no $\mathrm{n}$ participatory. Thus, the authority has to be aware of this and try to improve.

\section{Timeliness:-}

Customer service is not merely provision of service with cooperative front line workers. Rather, the time taken to $\mathrm{p}$ rovide the service is a necessary factor.Thus, as time is a decisive factor, it is clear that delayed delivery of services will result in dissatisfaction of customers. The standard time set by the agency for all the services it provides is less than one hour.They spent one and more than one hour to get the service. Therefore, the authority has to strive to $\mathrm{m}$ eet the standard time.

\section{Employees Effect on Service delivery:-}

The extent literature on service quality indicates that most of the criteria by which customers evaluate the perceived quality of service, such as empathy, reliability, courtesy, assurance and even tangibility are all ass ociated with employee favorable behaviors and attitudes (Wilson and Frimpong, 2004). In line with this, the autho rity was practicing poor to employees' responsiveness. Thus, the authority has to continue strengthening this c ondition by providing incentives and creating different mechanisms that increase employees' willingness.

\section{Courteousness and helpfulness of the staff:-}

One of the principles to customer satisfaction and quality service is courtesy and helpfulness of staffs to cust omers. Customers should be treated with utmost consideration and respect in the service delivery process i.e. in communicating information, delivering service, and dealing with problems.Thus, the courteousness and help fulness of staff to customers is found to be in a bad condition. Thus, in order to continue the staff support as per requirement of the customer and to the best satisfaction of them, the authority needs to recognized and appreci ate the courteousness of its staffs.

\section{Customer satisfactions:-}

Delayed delivery of service and Lack of coordination with relevant stake holders reason are the main problems wh y customers are dissatisfied/ very dissatisfied in the authority. So, the authority needsto monitor customer expecta tions and satisfaction on a continuous basis and to be innovative in order to respond meaningfully to changes about $\mathrm{t}$ he customer's expectation since customer satisfaction is not static.

\section{Employees satisfaction with the salary and benefits from authority:-}

The interactive nature of service delivery places employees in a very critical role in the delivery of quality services. The interactive nature of the service delivery process means that employee customer interactions should be consid ered as an important facet in evaluating the job satisfaction of employees who interact with external customer s. To date there has been strong empirical evidence in support of the view that overall job satisfaction is critical to e mployee service performance quality. The apparent logic is that employees who are satisfied with their jobs generall $\mathrm{y}$ and with their pay particularly tend to be cooperative, helpful, and respectful to both coworkers and customer s. Thus, satisfied employees will deliver quality service to both internal and external customers. Therefore, the emplo yees are dissatisfied with the pay of the authority .

\section{Complaint Handling System of the Agency:-}

As one of the principles of quality service states, public organizations should device mechanisms to monitor whether services are delivered properly and as per the promised standard and if not to redress problems as quickly as possi ble. Customers should also be encouraged to file their complaints. A successful company is one that listen s open mindedly, acts appropriately, and uses customer's feedbacks to improve its service (Tiosroud, 1993 cited in Yekunoamlak, 2004). In this regard, authority had no clear system for complaint handling, had no perso $\mathrm{n}$ assigned to receive complaints and even they do not know how they can complain. 


\section{Summary Of The Findings, Conclusions And Recommendations:- Summary of the findings:-}

In modern, highly competitive business world, the key to sustainable competitive advantage lies indelivering high quality service that will, in turn, lead to satisfied customers. Customer satisfaction is considered a prereq uisite for customer retention and loyalty, and can help to boost profitability, market share and return on investment.T hus, to be successful in the current competitive environment, service organizations must streamline their service delivery systems and respond to everdiscerning customers' demands for efficient and quality services.

Adama transport Authority is one of the public institutions which facilitates, coordinates and promotes private in vestment in the city administration. This term paper assessed service delivery and customer satisfaction in the a uthority in relation to location, facilities, requirements and forms, transparency and participation, employees' effec $\mathrm{t}$ on service delivery and satisfaction on their job (salary, benefit and trainings), timeliness, customer satisfacti on and complaint handling, which are the best measure of customer satisfaction.

The major results on this research paper are:

$\checkmark$ The location of the authority is inconvenient because it does not have parking area; the building is dark, not clea $\mathrm{n}$ and with bad smell and unaccessible for photo copy service.

$\checkmark$ Concerning other facilities like over all comfort of the reception area, it is very bad because of the following reasons:

$\checkmark$ The size of the reception is very small to serve many peoples at a time

$\checkmark \quad$ There are no reading materials like brochures, magazines, guidelines etc

$\checkmark$ No entertainment facilities like TV, classical music, tea and coffee service

$\checkmark$ The place where the reception located is obstacle for other office

$\checkmark \quad$ Lack of clean and easily accessible toilet

$\checkmark$ In terms of giving information, the agency is on the inexistence.

$\checkmark$ Concerning the fulfillment of manpower and office with the necessary facilities as well as provision of skille $\mathrm{d}$ based trainings and incentives, the authority lack partial fulfillment of office with the necessary facilities and confirmed the existence of low provision of skilled based trainings and incentives.

$\checkmark$ As far as the requirements and forms concerned the authority the requirements are unfair.

$\checkmark$ The authority is found in a bad position concerning transparency and consultation to and with clients since mo st of the respondents viewed the service delivery as transparent and confirm the existence of good consultatio n.

$\checkmark$ Regarding meeting the standard time, the authority was not served with in the standard time.

$\checkmark$ Based on the criteria by which customers evaluated the perceived quality of service such as reliability, respons iveness, assurance, empathy and even tangibility, the employees of the authority are found in a bad.

$\checkmark$ Concerning compliant handling system, the authority is found in a bad position, because of the following reasons

$\checkmark$ There is no clear system for complaint handling

$\checkmark \quad$ No person assigned to receive complaints

$\checkmark \quad$ Even they do not know how they can complain

\section{Conclusions:-}

The result of the study indicated that inaccessibility of photo copy service creates inconveniences and dissati sfaction on the investors. Besides, manpower and offices with the necessary facilities are found to be partially fulfill ed. The other factors related to the athority services delivery were the existence of problems related to location, reception area, meeting standard time and compliant handling system.Concerning employees of the authority, $\mathrm{t}$ hey were not satisfied because of low salary scale, poor workingconditions and low provision of skilled based tr aining and incentives. Thus, to curb the problems, the researcher forwarded suggestions in the recommendation part accordingly. 


\section{Recommendations:-}

Based on the findings of the study and the conclusions made above, the following recommendations are forwa rded:-

$\checkmark \quad$ The authority should develop mechanism that helps the customers to get photo copy service easily.

$\checkmark$ Either there should be latest lifts or the authority should be located at the first floor

$\checkmark$ The authority in collaboration with the institutions found within the building should install enough electric light especially in the stairs.

$\checkmark$ The authority should strive to meet its standard time. And it should have a recording mechanism of actua 1 performance vs. standards so that it would be easier to take corrective measures.

$\checkmark \quad$ By its special nature the customers of investment need not only mere fast service but also comfortable service. So, taking this in to consideration the authority should fulfill all the necessary facilities like clean and wide re ception room with enough and comfortable chairs, reading materials, TV with world wide information, news, cl assical music, tea and coffee service,clean accessible toilet,enough parking area, special desk which provides in formation. Besides, it has to give due attention for fulfilling offices with necessary facilities and keep them clea $\mathrm{n}$ and attractive.

$\checkmark \quad$ The authority should accept the generally accepted view that "satisfied employees

1. make satisfied customers" and invest in its employees to motivate them to serve customers best.

2. Employees should be trained to act in a manner that recognizes customers as a valuable asset

3. To motivate employees and get their commitment the authority should offer them attractive salary, mo netary and non-monetary

4. benefits. Unless otherwise the authority satisfies its employees turn over will

5. increase more thus, the current good performance may not continue and it may be

6. difficult for further improvemt

$\checkmark$ The authority should fulfill all the necessary manpower to provide all the services on timely bases.

$\checkmark$ Since for developing countries like Ethiopia, investment is the best way for reducing poverty, the authorit y Agency should integrated and work in coordination with the relevant offices and maximize the returns/out co mes of investment.

$\checkmark \quad$ The authority should establish efficient and effective ways of complaint handling procedures and communicate $\mathrm{t}$ hose procedures to customers.

\section{References:-}

1. Economic Commission for Africa (ECA) (2005). Public Private partnerships for service delivery: Water and san itation. Addis Ababa, Ethiopia.

2. Economic Commission for Africa (ECA) 2003. Public sector Management Reforms in Africa. Addis Ababa, Et hiopia.

3. Federal Democratic Republic of Ethiopia (FDRE) 2001. Service delivery Policy in the civil service. Addis Abab a, Ethiopia.

4. Yekunoamlak(2004)The impact of customer service on customer satisfaction and loyalty: a study of insurance companies in Ethiopia. Unpublished masters thesis, Addis Ababa university, Addis

Ababa Sschacter (2000) Financial Reform in a Devolved African Country: Lessons from Ethiopia. Public Administrati on and Development21, 131-146

5. Fadia and fadia (2008). Service Marketing. New York, Harper Collins College Publishers.

6. Gaster and Squires, (2003) . Alternative service delivery and public service transformation in South Africa, 1 4(3): 241-265.

7. Schacter,M. 2000. Public Sector Reform in Developing Countries: Issues, Lessons and Future Directions. Ottaw a: anadian International Development Agency.

8. Lane, (2000) The relationship between Service Quality and Customer Satisfactiona factor specific approach, Service Marketing, 16(4): 363-379

9. Donnelly et. Al (1992) Total Quality Management (TQM) in the Service Sector. Mumbai, Jaico Publishing Hou se

10. Donald Water (2002) The impact of foreign direct investment on economic growth: an empirical analysis of cen tral and eastern European countries. European journal of management.

11. Kotler (2003) Quality assurance in investment service, Managing Service Quality, 9(4): 222-230.

12. Avashiand Maheshwari (2007). Sources of public service improvement: a critical review an research agenda. Journal of public Administration Research and 
Acronyms and Abrevations

NPM_ New Public Management

ICT__ Information and Communication Technology

ECA_Commission for Africa

TQM_L_Total Quality Management

FDRE__ Federal Democratic Republic of Ethiopia

TV_ Television

$\mathrm{Km}$ Kilometer

$\mathrm{NB}:$ Note that

\section{Acknowledgment:-}

We are grateful thanks to Adama Transport Authority for its financial and technical support researchers also very i ndebted to extend our gratitude to Sample respondents for giving available and important data. Authors are als o thankful to the respondents who offered their time to participate in this study. 